\title{
Perbedaan Pengaruh Terapi Psikoreligius dengan Terapi Musik Klasik terhadap Kecemasan Pasien Pre Operatif di RSUD dr. H. Abdul Moeloek Provinsi Lampung
}

\author{
El Rahmayati ${ }^{1}$, Ririn Sri Handayani ${ }^{2}$ \\ ${ }^{1,2}$ Jurusan Keperawatan, Politeknik Kesehatan Tanjungkarang \\ Email: elrahmayati@poltekkes-tjk.ac.id
}

\begin{abstract}
The Differences Influence Psychoreligious Therapy with Classical Music Therapy on Pre Operation Patient in RSUD dr. H. Abdul Moeloek Lampung Province. The surgical procedure for most patients triggers anxiety and fear. Approximately $60-80 \%$ of patients who will undergo surgery experience anxiety that needs to be intervened in the category of moderate to severe anxiety (Efendy, 2005 in Faradisi, 2012). This study aims to determine the effect of psychoreligious therapy and classical music therapy on pre operative patient anxiety in RSUDAM Lampung Province in 2016. This research type is quasi-experiment research with non-equivalent control group design. This research was conducted at RSUDAM Lampung Province in SeptemberNovember 2016 in three surgical wards: the gelatik room (orthopedic surgery), the kutilang room (male general surgery) and the rose room (female general surgery). The population taken were all pre operative patients within the study period. The sampling technique uses a purposive method and the sample size is 80 people divided into 2 groups ie the group which is given the classical music intervention and the group that is given psycho-religious therapy with religious music and murrotal Al Quran surah Arrahman. The data were collected using a survey of Zung Self Anxiety Rating Scale (ZSARS) instruments before and after treatment. Bivariate analysis was performed using independent t-test statistic test by setting Alpha value 0,05 and 95\% CI. The results of this study conclude that there are differences of psycho-religious therapy and classical music therapy on pre operative patient's anxiety at RSUDAM Lampung Province 2016 (p-value 0,030) with a decrease of ZSARS score in patients treated with psycho-religious therapy 2,250. Researchers suggested that psycho-religious therapy performed on pre operative patients at RSUDAM Lampung Province and entered into one form of intervention to decrease preoperative anxiety.
\end{abstract}

Keywords: Anxiety, classical music, Psychoreligius

\begin{abstract}
Abstrak: Perbedaan Pengaruh Terapi Psikoreligius dengan Terapi Musik Klasik terhadap Kecemaasan Pasien Pre Operatif di RSUD dr. H. Abdul Moeloek Provinsi Lampung. Prosedur operasi bagi sebagian besar pasien mencetuskan perasaan cemas dan ketakutan. Sekitar $60-80 \%$ pasien yang akan menjalani operasi mengalami kecemasan yang perlu diintervensi yaitu dalam kategori kecemasan sedang hingga berat (Efendy, 2005 dalam Faradisi, 2012). Penelitian ini bertujuan untuk mengetahui perbedaan pengaruh terapi psikoreligius dan terapi music klasik terhadap kecemasan pasien pre operatif di RSUDAM Provinsi Lampung Tahun 2016. Jenis penelitian ini adalah penelitian kuasi eksperimen dengan desain non equivalent control group. Penelitian ini dilaksanakan di RSUDAM Provinsi Lampung pada bulan September-November 2016 di tiga ruang rawat bedah yaitu ruang gelatik (bedah orthopedic), ruang kutilang (bedah umum pria) dan ruang mawar (bedah umum wanita). Populasi yang diambil adalah semua pasien pre operatif dalam kurun waktu penelitian. Teknik sampling menggunakan metode purposive dan besar sampel sebanyak 80 orang yang dibagi ke dalam 2 grup yakni grup yang diberikan intervensi musik klasik dan grup yang diberikan terapi psiko-religius dengan musik religi dan murrotal $\mathrm{Al}$ Quran surah Arrahman. Pengumpulan data dilakukan dengan survey menggunakan instrumen Zung Self Anxiety Rating Scale (ZSARS) sebelum dan sesudah perlakuan. Analisis Bivariat dilakukan menggunakan Uji statistik $t$-test independent dengan menetapkan nilai Alpha 0,05 dan 95\% CI. Hasil penelitian menyimpulkan ada perbedaan pengaruh terapi psiko-religius dan terapi music klasik terhadap kecemasan pasien pre operatif di RSUDAM Provinsi Lampung tahun 2016 ( $p$-value 0,030$)$ dengan penurunan skor ZSARS pada pasien yang diterapi dengan terapi psikoreligius sebesar 2,250. Peneliti menyarankan agar terapi psiko-religius dilakukan pada pasien pre operasi di RSUDAM Provinsi Lampung dan dimasukkan ke dalam salah satu bentuk intervensi menurunkan kecemasan pre operatif.
\end{abstract}

Kata kunci: Kecemasan, Musik klasik, Psiko-religius 
Kecemasan (ansietas) merupakan respon individu terhadap suatu keadaan yang tidak menyenangkan dan dialami oleh semua makhluk hidup dalam kehidupan sehari-hari. Kecemasan dikomunikasikan secara interpersonal dan merupakan bagian dari kehidupan sehari-hari, menghasilkan peringatan yang berharga dan penting untuk upaya memelihara keseimbangan diri dan melindungi diri (Suliswati, 2005).

Tindakan operasi atau pembedahan merupakan pengalaman yang sulit bagi hampir semua pasien.berbagai kemungkinan buruk bisa saja terjadi yang akan membahayakan pasien. Respon kecemasan merupakan sesuatu yang sering muncul pada pasien yang akan menjalani operasi (pre operasi). Sering kali pasien dan keluarganya menunjukkan sikap yang agak berlebihan dengan kecemasan yang mereka alami.Kecemasan yang mereka alami biasanya terkait dengan segala macam prosedur asing yang harus dijalani pasien dan juga ancaman terhadap keselamatan jiwa akibat prosedur pembedahan dan pembiusan.

Keperawatan pre operatif merupakan tahapan awal dari keperawatan perioperatif. Kesuksesan tindakan pembedahan secara keseluruhan sangat tergantung pada fase ini karena fase pre operatif merupakan awal yang menjadi landasan untuk kesuksesan tahapantahapan berikutnya. Kesalahan yang dilakukan pada tahap ini akan berakibat fatal pada tahap berikutnya (Paryanto, 2009).

Penelitian Sawitri (2004) di RS Islam Kustati Surakarta, menunjukkan bahwa jumlah pasien yang tidak mengalami kecemasan sebanyak 22,4\%, dan sisanya mengalami kecemasan sebesar 77,6\%. Penelitian Makmuri et.al (2007) dalam Paryanto (2009) tentang tingkat kecemasan pre operasi terhadap 40 orang responden terdapat $40,0 \%$ mengalami tingkat kecemasan sedang, 37,5\% dalam kategori ringan, sebanyak $17,5 \%$ mengalami kecemasan berat dan $5 \%$ responden tidak merasa cemas. Beberapa orang kadang tidak mampu mengontrol kecemasan yang dihadapi, sehingga terjadi disharmoni dalam tubuh. Hal ini akan berakibat buruk, karena apabila tidak segera diatasi akan meningkatkan tekanan darah dan pernafasan yang dapat menyebabkan pendarahan baik pada saat pembedahan ataupun pasca operasi. Intervensi keperawatan yang tepat diperlukan untuk mempersiapkan klien baik secara fisik maupun psikis sebelum dilakukan operasi (Efendy, 2005 dalam Faradisi, 2012).

Terapi yang dikembangkan untuk kalangan pasien muslim adalah terapi memperdengarkan Murottal Al Qur'an. Lestari
(2015) dalam penelitiannya di RS dr. Soedarso Pontianak menyimpulkan bahwa ada pengaruh yang signifikan terapi murottal terhadap tingkat kecemasan pasien Penyakit Jantung Koroner di Ruang ICCU ( $\mathrm{t}_{\text {hitungs }}$ sebesar 9,812 $(p=0,000=0,05)$. Handayani dkk (2014) dalam penelitiannya terhadap penurunan nyeri dan kecemasan pada ibu bersalin kala 1 aktif menyimpulkan ada perbedaan rerata penurunan tingkat kecemasan sebelumdan sesudah dilakukan terapi murottal dengan nilai $p$-value $<a \quad(0,000<0,05)$. Penelitian Faradisi (2012) terhadap pasien fraktur membuktikan bahwa terapi music klasik dan terapi murrotal terbukti dapat menurunkan tingkat kecemasan yang diukur dengan Hamilton Rating Scale Anxiety (HRSA) dan terapi murottal lebih efektif dalam menurunkan tingkat kecemasan (nilai t sebesar 2,946 $(p=0,000<0,05)$ namun Faradisi tidak mempublikasikan jenis musik klasik dan surah Alquran yang digunakan.

Meskipun musik merupakan unsur yang universal namun musik tidak dapat menggantikan kebutuhan spiritual bagi sebagian individu termasuk juga umat muslim. Kebutuhan spiritual dapat dipenuhi melalui intervensi-intervensi psikologis dan fisik yang bernuansa religi berdasarkan agama dan keyakinan masingmasing individu. Membacakan kitab suci bagi sebagian individu kemungkinan akan lebih bermakna secara psikologis dan spiritual. Rumah Sakit yang berdiri atas dasar kemanusiaan berdasarkan ajaran agama tertentu biasanya akan menunjukkan identitasnya melalui aktifitas religi yang lebih menonjol dibandingkan rumah sakit biasa tanpa menghilangkan falsafah merawat tanpa membeda-bedakan agama, suku, ras dan kepercayaan.

\section{METODE}

Desain yang digunakan dalam penelitian ini adalah desain Quasi-experimental dengan desain pre post test. Pada penelitian ini responden penelitian akan dilakukan pengukuran tingkat kecemasan sebelum dan sesudah intervensi pada saat menjelang operasi. Waktu penelitian dilaksanakan pada bulan September s.d November 2016. Penelitian ini dilakukan di RS Abdul Moeloek Provinsi Lampung di tiga ruang rawat yaitu ruang gelatik (bedah orthopedic), ruang mawar (bedah wanita) dan ruang kutilang (bedah pria).

Populasi pada penelitian ini adalah semua pasien dewasa yang akan menjalani operasi di RSUD dr. H. Abdul Moeloek Provinsi Lampung Bulan September s.d November 2016 dengan 
estimasi populasi berdasarkan data RSUD dr. H. Abdul Moeloek Provinsi Lampung adalah ratarata 300 orang per bulan.

Perhitungan besar sampel yang diambil melalui uji hipotesis untuk penelitian eksperimen sederhana. Besar sampel yang dibutuhkan dalam penelitian ini peneliti tetapkan dengan nilai terbesar yaitu 20 orang per kelompok sampel sehingga jumlah keseluruhan sampel pada penelitian ini adalah 80 orang. Teknik pengambilan sampel (sampling) yang akan digunakan pada penelitian ini menggunakan metode Non Probability purposive sampling. Instrumen pengumpulan data dengan menggunakan kuisioner Zung Self Anxiety Rating Scale yang dibuat oleh William W. K. Zung M.D (1929-1992).

\section{HASIL}

\section{A. ANALISIS UNIVARIAT}

Analisis dilakukan pada setiap variabel dari hasil penelitian, baik variabel dependen maupun variabel independen serta karakteristik responden.

\section{Karakteristik Responden Penelitian}

Karakteristik responden penelitian berdasarkan umur, jenis kelamin, pendidikan, pekerjaan, Dx Medis dan sumber pembiayaan perawatan dapat dilihat pada tabel dibawah ini:

Tabel 1. Karakteristik Umur Responden

\begin{tabular}{ll}
\hline Variabel & \multicolumn{1}{c}{ Hasil } \\
\hline Umur & Mean : 42,39 tahun \\
& Modus : 36 tahun \\
& Min $: 15$ tahun \\
& Max $: 88$ tahun \\
\hline
\end{tabular}

Berdasarkan tabel di atas diketahui bahwa responden penelitian ini rata-rata berusia 42,39 tahun, dengan responden terbanyak berusia 36 tahun. Rentang usia seluruh responden antara 15 tahun hingga 88 tahun.
Tabel 2. Karakteristik Responden Penelitian

\begin{tabular}{lrr}
\hline \multicolumn{1}{c}{ Variabel } & n & \multicolumn{1}{c}{$\%$} \\
\hline Jenis Kelamin & & \\
Perempuan & 30 & 37,5 \\
Laki-laki & 50 & 62,5 \\
\hline Agama & & \\
Islam & 74 & 92,5 \\
Kristen & 6 & 7,5 \\
\hline Pendidikan & & \\
SD-SLTP & 56 & 76 \\
SLTA & 22 & 27,5 \\
PT & 2 & 2,5 \\
\hline Pekerjaan & & \\
Bekerja & 49 & 61,25 \\
Tidak Bekerja & 31 & 38,75 \\
\hline
\end{tabular}

2. Gambaran Tanda Vital Sebelum dan Sesudah Perlakuan

Berdasarkan hasil pengukuran terhadap tanda-tanda vital (Tekanan darah, frekuensi denyut nadi, dan respirasi rate sebelum dan sesudah perlakuan baik dengan terapi psikoreligius maupun dengan musik klasik didapatkan data sebagai berikut:

Tabel 3. Gambaran Tanda Vital Responden Penelitian Sebelum dan Sesudah Perlakuan

\begin{tabular}{|c|c|c|c|}
\hline Variabel & Mean & $\begin{array}{l}\text { SE } \\
\text { SD }\end{array}$ & $\begin{array}{l}\text { Min - } \\
\text { Max }\end{array}$ \\
\hline $\begin{array}{l}\text { TD Sistolik Sebelum } \\
\text { Intervensi }\end{array}$ & 121,76 & $\begin{array}{r}1,833 \\
16,392\end{array}$ & $95-200$ \\
\hline $\begin{array}{l}\text { TD Diastolik } \\
\text { Sebelum Intervensi }\end{array}$ & 78,73 & $\begin{array}{r}1,222 \\
10,929\end{array}$ & $50-120$ \\
\hline Nadi sebelum & 83,26 & $\begin{array}{l}0,686 \\
6,139\end{array}$ & $\begin{array}{r}60 \\
102\end{array}$ \\
\hline $\begin{array}{l}\text { Respirasi Rate } \\
\text { sebelum }\end{array}$ & 21,54 & $\begin{array}{l}0,185 \\
1,653\end{array}$ & $\begin{array}{l}18 \\
26\end{array}$ \\
\hline $\begin{array}{l}\text { TD Sistolik Sesudah } \\
\text { Intervensi }\end{array}$ & 117,85 & $\begin{array}{r}1,818 \\
16,258\end{array}$ & $91-200$ \\
\hline $\begin{array}{l}\text { TD Diastolik } \\
\text { Sesudah Intervensi }\end{array}$ & 76,99 & $\begin{array}{r}1,127 \\
10,083\end{array}$ & $55-120$ \\
\hline Nadi sesudah & 82,05 & $\begin{array}{l}0,478 \\
4,275\end{array}$ & $\begin{array}{l}72 \\
96\end{array}$ \\
\hline $\begin{array}{l}\text { Respirasi Rate } \\
\text { sesudah }\end{array}$ & 20,31 & $\begin{array}{l}0,151 \\
1,346 \\
\end{array}$ & $\begin{array}{l}16 \\
24 \\
\end{array}$ \\
\hline
\end{tabular}

Dari tabel di atas diketahui bahwa tekanan darah sistolik responden rata-rata sebelum perlakuan adalah 121,76 $\mathrm{mmHg}$ dan diastolik rata-rata $78,73 \mathrm{mmHg}$ dengan rentang tekanan darah sistolik antara $95-200 \mathrm{mmHg}$ dan diastolik 50-120 mmHg. Setelah perlakuan rata-rata tekanan darah sistolik responden turun menjadi $117,85 \mathrm{mmHg}$ dengan renang $91-200 \mathrm{mmHg}$, sedangkan tekanan darah diastolik juga turun menjadi $76,99 \mathrm{mmHg}$ dengan rentang 55-120 mmHg. Frekuensi denyut nadi responden 
sebelum perlakuan rata-rata $83,26 \mathrm{kali} /$ menit dengan rentang frekuensi denyut nadi sebanyak 60-102 kali/menit. Setelah perlakuan rata-rata frekuensi denyut nadi responden menurun menjadi 82,05 kali/menit dengan rentang frekuensi 72-96 kali/menit. Sedangkan repirasi rate responden sebelum perlakuan rata-rata 21,54 $\mathrm{kali} / \mathrm{menit}$ dengan rentang frekuensi sebanyak 18$26 \mathrm{kali} / \mathrm{menit}$, sesudah perlakuan rata-rata repirasi rate menurun menjadi $20,31 \mathrm{kali} /$ menit dengan rentang frekuensi menjadi 16-24 kali/menit.

\section{Gambaran Rata-rata Skor ZSRAS Sebelum dan Sesudah Perlakuan \\ Berdasarkan hasil pengukuran terhadap skor ZSRAS sebelum dan sesudah perlakuan baik dengan terapi psiko-religius maupun dengan musik klasik didapatkan data sebagai berikut:}

Tabel 4. Gambaran Rata-rata Skor ZSRAS Responden Penelitian Sebelum dan Sesudah perlakuan

\begin{tabular}{|c|c|c|c|}
\hline $\begin{array}{c}\text { Nilai } \\
Z S A R S\end{array}$ & Mean & SD & SE-Mean \\
\hline Sebelum & 23,91 & 4,816 & 0,538 \\
\hline Sesudah & 22,91 & 5,494 & 0,614 \\
\hline
\end{tabular}

Dari tabel di atas diketahui bahwa sebelum perlakuan rata-rata skor ZSARS responden adala 23,91 dengan $S D$ sebesar 4,816 dan SE Mear Psikoreligius sebesar 0,538. Sesudah perlakuan rata-rata skor ZSARS turun menjadi 22,91 dengan $S D$ sebesar 5,494 dan SE Mean sebesar 0,614.

\section{Rata-rata Selisih Nilai Zung Self Anxiety Rating Scale (ZSARS) pada Dua Kelompok Perlakuan}

Berdasarkan hasil analisis terhadap selisih skor ZSRAS sebelum dan sesudah perlakuan baik dengan terapi psiko-religius maupun dengan musik 97 klasik didapatkan data sebagai berikut :

Tabel 5. Rata-rata Selisih Nilai Zung Self Anxiety Rating Scale (ZSARS) Sebelum dan Sesudah Perlakuan pada Dua Kelompok $\left(n_{1=} 40, n_{2}=40\right)$

\begin{tabular}{ccccc}
\hline $\begin{array}{c}\text { Selisih } \\
\text { Nilai ZSARS }\end{array}$ & Mean & SD & SE-Mean \\
\cline { 1 - 1 } Musik Klasik $\left(\mathrm{n}_{1}\right)$ & $-0,050$ & 4,596 & 0,727 \\
Psikoreligius $\left(\mathrm{n}_{2}\right)$ & 2,250 & 4,721 & 0,746 \\
\hline
\end{tabular}

Dari tabel di atas diketahui bahwa rata-rata selisih skor ZSRAS pada kelompok perlakuan menggunakan musik klasik adalah -0,050 dengan $S D$ 4,596 dan SE-Mean 0,727. Sedangkan selisih rata-rata skor ZSRAS pada kelompok perlakuan menggunakan terapi psiko-religius (mendengarkan murrotal Qur'an Surah Ar-rahman atau mendengarkan musik religi Kristen) adalah 2,25 dengan $S D$ 4,721 dan SE-Mean 0,746.

\section{B. ANALISIS BIVARIAT}

Analisis bivariat dilakukan untuk menjawab hipotesis penelitian berdasarkan parameter statistik. Dengan menetapkan alpha 0,05 dan confidence interval 95\%, hasil analisis bivariat terhadap perbedaan pengaruh terapi psikoreligius dan terapi musik klasik terhadap penurunan kecemasan pasien pre operative di RSUD dr. H. Abdul Moeloek Provinsi Lampung dapat dilihat pada tabel berikut ini:

Tabel 6. Analisis Perbedaan Pengaruh Terapi Psikoreligius dan Terapi Musik Klasik terhadap Penurunan Kecemasan Pasien Preoperative

\begin{tabular}{lccccc}
\hline Variabel & $\begin{array}{c}\text { Mean } \\
\text { selisih } \\
\text { sebelum } \\
\text { dan } \\
\text { sesudah } \\
\text { intervensi }\end{array}$ & SD & SE & $\begin{array}{c}\text { Sig } \\
\text { 2-tailed) }\end{array}$ & $\begin{array}{c}\mathbf{9 5 \%} \\
\text { CI } \\
\text { Lower } \\
\text { Upper }\end{array}$ \\
\hline Musik Klasik & $-0,050$ & 4,596 & 0,726 & 0,030 & 4,374 \\
Psikoreligius & 2,250 & 4,722 & 0,746 & & 0,226 \\
\hline
\end{tabular}

Dari tabel diatas diketahui bahwa rata-rata selisih skor ZSRAS pada kelompok perlakuan menggunakan musik klasik adalah -0,050 dengan $S D$ 4,596 dan SE-Mean 0,727. Sedangkan selisih rata-rata skor ZSRAS pada kelompok perlakuan menggunakan terapi psiko-religius (mendengarkan murrotal Qur'an Surah Ar-rahman atau mendengarkan musik religi Kristen) adalah 2,25 dengan $S D$ 4,721 dan SE-Mean 0,746. Hasil analisis bivariat dengan t-test independent pada Alpha 0,05 dan CI 95\% didapatkan p-value sebesar 0,05 $(<$ Alpha $)$ dengan demikian hasil analisis bivariat memutuskan hipotesis penelitian gagal ditolak atau ada perbedaan pengaruh terapi psikoreligius dengan terapi musik klasik terhadap penurunan kecemasan (skor ZSRAS) pada pasien pre operatif di RSUDAM Provinsi Lampung.

\section{PEMBAHASAN}

Hasil analisis data pada penelitian ini diperoleh data rata-rata skor ZSRAS responden sebelum diberikan perlakuan adalah 23,91 dimana menurut skala ZSRAS nilai 23,91 masuk 
dalam kategori kecemasan ringan (20-34). Menurut Stuart (1998) tingkat kecemasan ringan yang dialami responden berhubungan dengan ketegangan dalam kehidupan akibat adanya stressor dari luar. Kecemasan ringan juga dianggap sebagai respon normal terhadap stressor yang dialami individu. Secara umum rasa cemas dimiliki oleh setiap individu, kecemasan merupakan respon yang paling umum yang menyatakan kondisi "waspada".

Menghadapi tindakan operasi merupakan stresoor tersendiri bagi sebagian besar pasien. Beberapa kekhawatiran muncul terkait dengan tindakan yang akan dilakukan. Orang dewasa membayangkan ketakutannya akan tindakan anestesi yang membuatnya tidak sadarkan diri selama prosedur operasi berlangsung, instrumen bedah yang sebagian besar terbuat dari logam, suara alarm monitor pasien, suhu kamar operasi yang dingin dan nyeri luka operasi setelah sadar dari pengaruh anestesi. Meskipun kini tidak semua operasi membutuhkan anestesi umum.

Tingkat pendidikan, pengetahuan, pengalaman operasi sebelumnya, informasiinformasi baik positif maupun negatif tentang tindakan operasi juga mempengaruhi perasaan cemas seorang pasien yang akan menjalani operasi. Pada penelitian ini, sebagian besar responden berpendidikan SD-SLTP (76\%), jenis kelamin mayoritas laki-laki $(62,5 \%)$ dan usia rata-rata $42,39 \%$. Dengan tingkat pendidikan yang tergolong rendah, umumnya individu akan kesulitan memahami penjelasan yang terlalu kompleks dan memiliki sikap yang cenderung pasrah serta tidak banyak bertanya atau mencari informasi. Apabila ada hal-hal yang membuatnya merasa cemas, takut atau keingintahuan yang mendalam umumnya mereka enggan bertanya sehingga koping terhadap kecemasan di represi secara internal didalam dirinya sendiri.

Setelah dilakukan tindakan dengan memperdengarkan musik klasik pada sekelompok responden dan memperdengarkan murrotal Al Qur'an Surah Arrahman atau musik religi Kristen sesuai dengan agama masingmasing responden, tampak adanya penurunan skor ZSRAS menjadi 22,91. Secara kuantitatif penurunan ini bermakna karena menunjukkan adanya perbedaan skor sebelum dan sesudah diberikan perlakuan. Meskipun secara kualitatif skor 22,91 masih termasuk kedalam kategori kecemasan ringan. Namun jika dilihat dari parameter penunjang lainnya seperti tanda-tanda vital tampak adanya perubahan tanda-tanda vital sebelum dan sesudah perlakuan. Tekanan darah rata-rata responden sebelum perlakuan
121,76/78,73 mmHg turun menjadi 117,85/76,99 mmHg. Frekuensi denyut nadi dari 83,26 $\mathrm{kali} /$ menit turun menjadi $82,05 \mathrm{kali} / \mathrm{menit}$ dan respirasi rate dari $21,54 \mathrm{kali} / \mathrm{menit}$ turun menjadi 20,31 kali/menit.

Perubahan tanda-tanda vital adalah salah satu manifestasi klinis obyektif dari kecemasan. Pada penelitian ini jika dilihat nilai rata-rata tekanan darah, nadi dan pernafasan semua masih dalam batas normal baik sebelum maupun sesudah perlakuan. Hal ini sesuai dengan skor ZSRAS yang menunjukkan bahwa rata-rata responden berada dalam kondisi kecemasan ringan. Kecemasan ringan berupa perasaan khawatir dan waspada terhadap bahaya yang mengancam namun tidak membuat individu yang mengalaminya menjadi ketakutan sehingga membuat perubahan tanda vital yang bermakna seperti peningkatan tekanan darah, peningkatan denyut jantung dan irama pernafasan. Kecemasan ringan pada beberapa individu justru meningkatkan rasa keingintahuan terhadap hal yang membuatnya cemas sehingga individu tersebut menjadi banyak bertanya, meningkatkan kreatifitas dan dapat didorong untuk melakukan hal-hal positif. Namun demikian, kecemasan ringan yang tidak difasilitasi untuk diturunkan tingakatannya atau dipenuhi kebutuhan informasi yang diinginkan dapat meningkat menjadi kecemasan sedang bahkan berat.

Namun bila dilihat dari data minimalmaksimal nilai tanda-tanda vital ada responden yang tekanan sistoliknya mencapai $200 \mathrm{mmHg}$ dan diastolik 50-121 mmHg. Menurut JNC VII tekanan sistolik $>160 \mathrm{mmHg}$ dan diastolik $>90$ $\mathrm{mmHg}$ termasuk ke dalam kategori hypertensi. Tekanan darah yang tinggi tentu menjadi penyulit bagi tindakan operasi. Seorang pasien yang mengalami hypertensi menjelang memasuki kamar operasi, dapat dibatalkan tindakan operasinya untuk menghindari komplikasi dan bahaya intraoperatif. Meskipun setelah perlakuan rata-rata responden mengalami penurunan tekanan darah namun rentang sistolik tertinggi masih $200 \mathrm{mmHg}$, menurut peneliti hal ini menarik untuk diteliti lebih lanjut apakah efek relaksasi yang diharapkan dari memperdengarkan musik klasik maupun terapi psiko-religius dapat mempengaruhi penurunan tekanan darah.

Hasil analisis bivariat penelitian ini menunjukkan adanya perbedaan pengaruh terapi psikoreligius dengan memperdengarkan murrotal Al Qur'an Surah Arrahman atau musik religi Kristen dibandingkan dengan memperdengarkan musik klasik Mozart terhadap penurunan kecemasan pada pasien pre operasi ( $p$-value $0,03<$ Alpha 0,05). Uji t-independent yang 
digunakan pada penelitian ini menganalisis perbedaan tersebut secara kuantitatif dengan menganalisis skor ZSRAS yang diperoleh responden. Secara kuantitatif perbedaan rata-rata skor pada kedua kelompok menunjukan adanya perbedaan pengaruh terhadap penurunan kecemasan responden. Jika dilihat dari hasil analisis univariat jelas tampak bahwa selisih skor sebelum dan sesudah perlakuan pada kelompok yang diberikan terapi psikoreligius lebih besar dibandingkan dengan kelompok yang diberi terapi musik klasik (2,25 dan - 0,05). Kelompok yang diberi terapi psikoreligius rata-rata mengalami penurunan skor dan sebaliknya pada kelompok yang diberikan terapi musik klasik ada yang mengalami peningkatan skor sehingga mempengaruhi nilai rata-rata skor dalam kelompok tersebut.

Mindlin (2009) dalam Faradisi (2012) menyatakan bahwa Ketika diperdengarkan musik klasik, maka harmonisasi dalam musik klasik yang indah akan masuk telinga dalam bentuk suara (audio), menggetarkan genderang telinga, mengguncangkan cairan diteling dalam serta menggetarkan sel-sel rambut di dalam koklea untuk selanjutnya melalui saraf koklearis menuju otak dan menciptakan imajinasi keindahan di otak kanan dan otak kiri. Yang akan memberikan dampak berupa kenyamanan dan perubahan perasaan. Perubahan perasaan ini diakibatkan karena musik klasik dapat menjangkau wilayah kiri kortek cerebri. Menurut Ganong (2005) dari korteks limbik, jaras pendengaran dilanjutkan ke hipokampus, dan meneruskan sinyal musik ke Amigdala yang merupakan area perilaku kesadaran yang bekerja pada tingkat bawah sadar, sinyal kemudian diteruskan ke hipotalamus. Hipotalamus merupakan area pengaturan sebagian fungsi vegetative dan fungsi endokrin tubuh seperti halnya banyak aspek perilaku emosional, jaras pendengaran diteruskan ke formatio retikularis sebagai penyalur impuls menuju serat otonom. Serat saraf tersebut mempunyai dua sistem saraf, yaitu saraf simpatis dan para simpatis. Kedua saraf ini dapat mempengaruhi kontraksi dan relaksasi organorgan. Relaksasi dapat merangsang pusat rasa ganjaran sehingga timbul ketenangan. Demikian juga dengan suara tartil yang dilantunkan dari pembacaan Al Qur'an. Meskipun Al Qur'an dibacakan dalam bahasa arab yang tidak semua orang Islam memahami artinya tetapi bacaan ayat-ayat Al Qur'an yang disuarakan dengan lagu tilawah akan memberikan efek menenangkan bagi umat muslim. Sebagian besar umat muslim merasa tenang perasaannya ketika mendengarkan bacaan Al Qur'an. Hal tersebut juga sama dengan umat kristiani yang mendengarkan lagu-lagu religi Kristen. Dalam peribadatannya, umat kristiani biasa menggunakan musik dan lagu-lagu rohani untuk menyampaikan isi kitab suci. Pada dasarnya respon fisiologis yang ditimbulkan sama dengan mendengarkan musik klasik namun memiliki kelebihan yaitu adanya nasehat-nasehat spiritual yang meningkatkan pengharapan positif kepada individu yang mendengarkannya.

Pada kenyataannya, data hasil penelitian ini menyatakan bahwa pada kelompok yang diterapi dengan musik klasik beberapa responden menunjukkanpeningkatan skor ZSRAS. Musik klasik Mozart yang diperdengarkan adalah musik yang diambil dari kumpulan The most relaxing classical music yaitu musik klasik Mozart yang sering digunakan untuk relaksasi. Alunan musik instrumentalia yang digubah dengan musikalitas tingkat tinggi, biasa diperdengarkan dalam konser-konser musik klasik maupun dikalangan tertentu misalnya dalam proses terapi, kehamilan, sekolah musik dan sebagainya mungkin kurang familiar didengar oleh responden yang notabene berpendidikan rata-rata rendah. Hal ini terbukti dari pengamatan peneliti lakukan selama proses pengambilan data. Beberapa responden yang terpilih secara random sebagai responden dalam kelompok musik klasik tampak berusaha menikmati musik yang didengarnya dan beberapa orang secara non verbal menampilkan ekspresi kurang menikmati musik klasik yang didengarnya terutama responden yang lansia (>60 tahun).

Pada kelompok yang diperdengarkan Murrotal AL Qur'an Surah Arrahman atau musik religi Kristen lebih efektif dalam penurunan nilai ZSRAS. Surah Arrahman adalah salah satu surah dalam Al Qur'an yang berisi kandungan ayatayat yang mengajarkan manusia untuk bersyukur atas karunia dan nikmat yang diberikan oleh Allah SWT. Ayat-ayat dalam surah Arrahman mengajarkan umat muslim untuk tidak bersedih dan berputus asa serta mensyukuri apa yang dimiliki saat ini dengan tidak memikirkan apa yang tidak dimiliki. Penelitian Faradisi (2012) pada pasien pre operasi fraktur menyimpulkan terapi murotal efektif menurunkan tingkat kecemasan pasien (nilai t hitung sebesar 10,920 $(p=0,000<0,05)$ dibandingkan dengan pemberian terapi terapi musik ( $\mathrm{t}$ hitung sebesar 2,946 $(p=0,000<0,05)$. Demikian juga penelitian Lestari (2014) terhadap pasien penyakit jantung koroner di Ruang ICCU RS Dr. Soedarso Pontianak menyimpulkan ada pengaruh terapi murottal terhadap tingkat kecemasan pasien dengan penyakit jantung koroner di ruang ICCU RSUD dr. Soedarso Pontianak $(p=0,000=0,05)$. 
Penelitian Handayani, dkk (2014) terhadap ibu bersalin kala 1 fase aktif juga menunjukkan bahwa ada perbedaan rerata penurunan tingkat kecemasan sebelum dan sesudah dilakukan terapi murottal dengan nilai $p$-value $<\alpha(0,000<0,05)$.

Menurut peneliti, pada umumnnya masyarakat Indonesia adalah masyarakat yang religius. Beraneka ragam agama dan kepercayaan tumbuh dan berkembang dengan baik. Nilai-nilai keyakinan dijaga keberlangsungannya dalam kehidupan sebagian besar masyarakat tidak hanya di pedesaan tapi juga di wilayah perkotaan (penduduk urban). Individu yang memiliki keyakinan akan keberadaan Tuhan Yang Maha Kuasa memiliki kekuatan dan pengharapan yang lebih baik karena memiliki tempat untuk meminta kesembuhan, keselamatan dan perlindungan melalui berdoa. Masing-masing umat beragama memiliki cara sendiri dalam beribadah dan mengembalikan kekuatan psikospiritualnya. Individu ini memiliki tempat untuk meletakkan semua beban kehidupan secara psikologis dan keyakinan yang kuat untuk mendapat pertolongan dari Tuhan Yang Maha Kuasa sehingga ketika diperdengarkan kepada mereka ayat-ayat kitab suci atau syair dalam musik religi mereka merasa lebih tenang, rileks dan memiliki kekuatan secara psikologis bahwa apapun yang akan terjadi mereka pasti mendapatkan pertolongan. Berbeda dengan musik klasik yang memperdengarkan tinggi rendah nada dengan seni musikalitas, musik klasik mungkin dapat memberikan efek menenangkan namun karena tidak mengandung nilai-nilai religius tidak mampu memberikan efek psikologis pengharapan positif dan keyakinan akan mendapat pertolongan dari zat yang Maha Kuasa. Menurut peneliti, bagi masyarakat Indonesia ke-2 terapi ini dapat diberikan kepada pasien pre operasi namun bagi masyarakat Indonesia yang religius terapi psiko-religius berdasarkan nilai-nilai agama lebih tepat untuk menurunkan kecemasan dibandingkan dengan memperdengarkan musik klasik karena sesuai dengan nilai-nilai yang ada dalam sebagian besar diri individu.

\section{SIMPULAN}

Berdasarkan hasil analisis data dan pembahasan yang telah diuraikan dalam bab sebelumnya pada penelitian ini, peneliti menyimpulkan hasil penelitian sebagai berikut :

1. Ada pengaruh terapi musik klasik terhadap penurunan tingkat kecemasan pasien pre operasi di RSUD dr. H. Abdul Moeloek Provinsi Tahun 2016.

2. Ada Pengaruh terapi psikoreligius terhadap penurunan tingkat kecemasan pasien pre operasi di RSUD dr. H. Abdul Moeloek Provinsi Tahun 2016.

3. Ada perbedaan pengaruh terapi psikoreligius dengan terapi musik klasik terhadap penurunan tingkat kecemasan pasien pre operasi di RSUD dr. H. Abdul Moeloek Provinsi Tahun 2016 ( $p$-value 0,03< $<0,05$ ).

\section{SARAN}

Berdasarkan kesimpulan hasil penelitian tersebut peneliti menyarankan:

1. Pasien pre operasi dapat diberikan pilihan untuk mendengarkan musik klasik atau terapi psikoreligius dengan mendengarkan murrotal Al Qur'an Surah Arrahman bagi yang beragama Islam dan mendengarkan musik religi Kristen bagi yang kristiani untuk memberikan efek relaksasi dan ketenangan sehingga menurunkan kecemasan menghadapi operasi.

2. Terapi psikoreligius dan terapi musik klasik dapat dijadikan standar intervensi dalam diagnosa keperawatan kecemasan pasien pre operasi oleh perawat di RSUD dr. H. Abdul Moeloek Provinsi Lampung.

3. Terapi psikoreligius dan terapi musik klasikdapat diajarkan kepada mahasiswa keperawatan sebagai tindakan untuk mengatasi kecemasan pasien pre operasi.

\section{DAFTAR PUSTAKA}

Faradisi, Firman. 2012. Efektifitas Terapi Murottal dan Terapi Musik Klasik terhadap Kecemasan Pasien Pra Operasi di Pekalongan. Jurnal Ilmiah Kesehatan, Vol V, No. 2, September 2012.

Ganong W.F. 2005. Review of medical physiology. 22nd ed. Singapore: Mc Graw Hill. p. 192-201.
Handayani, Rohmi dkk. 2014. Pengaruh terapi Murottal Al Qur'an terhadap Nyeri Persalinan dan Kecemasan Ibu Bersalin Kala 1 Fase Aktif. Jurnal Ilmiah Kebidanan, Vol. 5, No. 2, Edisi Desember 2014, hlm. 1-15.

Lestari, Dian. 2015. Pengaruh Terapi Murottal terhadap Tingkat Kecemasan Pasien 
dengan Penyakit Jantung Koroner di Ruang ICCU RSUD dr. Soedarso Pontianak. Proners, Vol. 3, No.1, 2015. Paryanto. 2009. Perbedaan Tingkat Kecemasan Pasien Pre Operatif Selama Menunggu Jan Operasi Antara Ruang Rawat Inap Dengan Ruang Persiapan Operasi Rumah Sakit
Ortopedi Surakarta. Skripsi. Universitas Muhammadiyah. Surakarta.

http://etd.eprints.ums.ac.id/4455/1/J210070 104.pdf

Stuart \& Sundeen. 1998. Prinsip dan Praktik Psikiatrik (Terjemahan). Jakarta: EGC.

Suliswati. 2005. Konsep Dasar Keperawatan Kesehatan Jiwa. Jakarta: EGC. 